\title{
Johannes Pause
}

\section{Expansions of the Instant}

\section{Disruptions of Time in Contemporary German Literature}

Time stands still in Thomas Lehr's novel 42. A cosmic “disruption” (Lehr 2005: 35) has caused a single moment to linger on for all eternity, time as an ephemeral experience has been suspended, brought to a standstill in the interface of a single, everlasting moment. The novel tells the story of the "chronified" (Chronifizierten), a small group of randomly assembled protagonists, who, for reasons that remain unknown to them as well as the reader, can continue to move through this frozen world, enclosed in their own small temporal spheres, in which their own private time goes on ticking as usual. The "time zombies," as they call themselves, soon begin to lead a nomadic existence: they traverse the world, which has become a mere backdrop, in which aircrafts hang motionless in the eternally cloudless sky and people remain frozen in mid-step. The visual presence of an - in principle - familiar reality, which is one of the major effects of the scenario, enters into a strangely incongruous relationship with its "unreality," with the mystery that the world of the eternal present seems to harbor. For in Thomas Lehr's work, time has stood still around midday, of all times, so that all of Europe is lit by never-ending bright sunlight, which literally illuminates reality right into the last nook and cranny. This maximum degree of visibility, this visual monumentalization of the existing world, is bound up with a deep ontological doubt: everything that is so clearly visible here suddenly seems like a facade, a copy, like a gigantic museum of the world, lacking the "wintery air of real reality"; it seems more like a "sculpture garden," populated by "mummies," "wax figures" and "shop window mannequins of a decorator suffering from delusions of grandeur” (Lehr 2005: 236, 33-34, 53 \& 63). Leitmotifs involving metaphors of art, images, and photography are used to describe this world, thus alluding to a context drawn from the theory of the media: the world brought to a standstill appears as the purest "summer painting, across which a brilliant photo-realist has scattered his highlights, his intimate hues and life-like shadows," like a "painting by Spitzweg," or rather "a film by Spitzweg, [...] in which in principle everything would be able to move," were it not fixed in the immobility of a single snapshot (Lehr 2005: 11, 124 \& 132). And elsewhere, concerning a spontaneous remark made by a "chronified" child, we read: "It seems to have been photographed, crystallized and fixed in place by the ad-

Translated from the German by Gregory Sims. 
hesive tape of the world - the child's formulation cannot be bettered, even for the third dimension." (Lehr 2005: 33) Like photography, the now-frozen reality is simultaneously a real presence and an artificial backdrop, simultaneously the present and the past, simultaneously a confirmation of the images in our memory and a de-familiarization of the familiar - "the living image of a dead thing” (Barthes 1981: 79), as Roland Barthes put it.

In the face of this omnipresence of timeless visuality, Lehr's protagonists reactivate the temporality of another, properly anachronistic medium, namely writing. "Whoever does not write will hardly be able to endure our world" (Lehr 2005: 161), says the protagonist, revealing his role as the fictional author of the text of the novel. But from the very beginning, writing is a losing battle against the overwhelming power of images; the attempt to rescue the temporality of writing from the presentist power of the visual is futile: "Imagine me as a stray dog that repeatedly lifts its writing leg on the lamppost of self-assurance." (Lehr 2005: 161$)^{1}$

Against the excess of an omnipresent visuality, writing as a cultural practice becomes almost meaningless. The novel could thus be interpreted as indicating that a crisis of literature is in the making, under the sign of multimedia imagery. Writing thus tends to be associated with time, whereas the image is associated with the present, presence, and timelessness: by writing, the protagonist bestows a story on his experiences, by writing he creates a difference between the present of the writing and the past of what is written, between sign and reference. The written word awakens memories of the time before the present; it makes what is simply there, in a presentist and banal way, into a trace of a past, a sign of something else that is no longer present. Time thus emerges as an expression of the cognitive power to distance oneself symbolically from the presence of what is perceived - a power which, according to Lehr's novel, finds itself in an increasingly bad way in a world of images.

The event that Lehr makes the starting point of his narrative is thus to be read as a mediatic disruption, which also affects the relationship of both the protagonist and literature to the world. The visibility of this world appears to be colliding with its legibility, and this conflict manifests itself in the form of the collapse of an habitual temporal distance: the event, which, as in crime fiction, is presented right at the beginning of the story, and for which the "chronified" endeavor to provide an explanation, is no longer an event in the sphere of history, from an inaccessible past, which can be reconstructed only on the basis of traces

1 "Man stelle sich einen streunenden Hund vor, wenn man sich mich vorstellt, der immer wieder das Schreibbein am Laternenpfahl der Selbstvergewisserung hebt.” 
(Derrida 2007); rather, it is brutally evident, constantly staring one in the face. In addition to time standing still, this also applies to all sorts of other cases in 42, such as the infidelity of the protagonist's girlfriend, which in this timeless world is presented in graphic clarity like a museum exhibit. No traces or indices have to be picked over here, no signs deciphered in order to identify the obvious. The disruption of the relationship is perpetuated in a kind of still life of infidelity. Only by means of a furious but ineffective manipulation of the image can it be put right, though not in historical time, which would enable the disruption to be integrated and thus normalized. The dynamic relationship between disruption and order is suspended, although there is still a suggestion of it in the novel's structure, with the five chapters comprising five phases of the (failed) processing of the event, beginning with the "shock" and ending in "fanaticism." The breakdown of a collectively binding time and temporality, the radical end of history in the timeless presence of the simulacrum, even leads to the collapse of the cultural function of narratives of disruption.

Against this background, the exploration of time in Lehr's novel and in the works of other authors can be read as a reflection on the mediatized nature of writing, as well as the function of literature and its poetics of disruption (Stegemann 2015: 65). For, in so far as the aesthetics of disruption are generally concerned with presence, and thus with creating effects of the present, the fantastic expansion of the present in Lehr's novel can also be read as a crisis of this form of reception aesthetics: if the attack of the present on the rest of time is already in full swing, if all routines have already been broken up and the disruption is set to last, why then go on trying to create enduring moments in the counterworlds of literature? Recent novels that thematize the contemporary world, such as 42, combine the return of a form of narration - one unable to produce any closure - with citations from modernist figures of reflection, which also no longer represent ruptures, but are rather to be read as symptoms of a crisis of literature. The main focus is on aesthetic concepts of disrupted continuity, a characteristic feature of classical modernity, which is known for its "obsessive thematization of time" (Middeke 2002: 9). Against a growing dictatorship of the clock, which had become steadily more important in the wake of modernization and industrialization (Mumford 1934: 14), becoming especially noticeable thanks to the worldwide synchronization of time zones around 1900 (Galison 2003), modernist literature of that era articulated experiences of temporal discontinuity. These experiences combined a criticism of modern life, in particular of urban life and its speed, with a longing for a more meaningful form of time, for a revaluation of the inner experience of time, against the monotonous, empty arrow of physical or historical time. 
The status of the present or the "moment" seems especially precarious in the literature of classical modernism. The immediate experience of presence in the present, of lingering "on the threshold of the moment," as Nietzsche once insisted (Nietzsche 1997: 62), forms one of the central phantasms of modern literature. At the same time, however, the possibility of a present and conscious experience of the moment is tendentially negated. In Hugo von Hofmannsthal's work, for example, one finds a veritable inability to live in the present, an inability that is essentially grounded in media theory: the translational power of a symbolically programmed mind introduces a gap between the moment of pure experience and its "coding” by the faculty of understanding, which is experienced as a loss of the present. The moment that passes is thus always only consciously perceptible when it has already passed; time itself emerges as the interval between an original experience and its retrospective comprehension, between the awareness of the moment and the moment of awareness. In order for "not just the experience of time, but time itself to be able to come into being [...] its non-being in every point in time, in every now its not-now must be simultaneously cognized" (Steiner 1996: 47). Uwe C. Steiner formulated this structure with reference to Derrida as follows:

What is referred to as the present is the result of an operation of observation, with itself as object and which it therefore necessarily fails to grasp. Time thus occurs in a dual form: as operative time, the time of performance, and as observed time, as a reference. [...] The present is thus reclaimed as a reference, thereby relying on a [...] performance that it cannot catch up with, which first produces it and which inevitably eludes it. (Steiner 1996: 48-49)

Against this background, it becomes clear why the problem of time in the literature of classical modernism is primarily a problem of writing: in the oscillation between the presence of the sign and the absence of its meaning, in the immobilizing of meaning in the letter and its revitalization in the act of writing or reading, the primal scene (Urszene) of time is in a way being repeated again and again. Since the "reference" of writing is necessarily "subordinated" to its "performance," that is, to its graphic image, writing creates an awareness of the absence of the designated present, an awareness that is itself experienced as time (Steiner 1996: 46). According to Christina von Braun, it was in the first instance the invention of "phonetic alphabetic writing," to which the West and "historically-minded man" owe their "unshakeable sense of security," namely the unity and irreversibility of time, "the unchangeability of what has been [des Gewesenen]” (von Braun 1999: 103).

In the literature of classical modernism, the temporality of writing is seen as being opposed to the instantaneousness of the pre-linguistic, in a way still uncoded perceptual image, which, in the service of a capacity for immediate expe- 
rience, is supposed to disrupt the assuring but also alienating certainty of writing. Sabine Schneider illustrates the contrast between image and language using the example of Hofmannsthal's novella Das Glück am Weg: here, during a boat trip, the protagonist catches a glimpse of a beautiful woman on another boat, and the sight of her immediately moves him. In its "fleeting, vague pictorial language," however, the moment remains pre-conscious, while its actual designation, which involves resorting to a concept, is only possible once the experience is already over. After the ship has passed by, its name becomes visible on the stern, "La Fortune": "As the gentle melancholic irony of the closing pointe puts it, only now, when the golden, glittering vision is extinguished and the golden gates to the inner eye are closed, does the previously unreadable name reveal its significance" (Schneider 2006: 293). Writing thus possesses a "melancholy structure of delay": it always arrives too late, fails to reach the goal of happiness, but at the same time the latter retains its meaning only through its subsequent designation. The "crisis of language," which has repeatedly been described as the central feature of classical modernism, is thus based on a crisis of temporal experience: language cannot do justice to reality because it always opens up a gap between what it means and the way in which this meaning is expressed. Around 1900, there was a widespread awareness that, compared to other, more sensual arts, literature had no means at its disposal in the struggle against the dead culture of concepts. Whereas the image "speaks directly to the soul," as Hofmannsthal himself once wrote (Hofmannsthal 1991: 169), language allows only a retrospective construction of reality, which distorts the original sensuous impressions and pictorial perceptions and renders them inaccessible, owing to a structure that is commensurable with the structure of conceptual thinking. In this way, rational language tends to be disempowered; it is now characterized by a lack, by its distance from life, which can be overcome only in rare moments of mute undifferentiatedness. To create such moments, a whole arsenal of new literary strategies is developed, designed to facilitate the simulation of pictorial effects of presence - this by disrupting diegesis, by empowering readers, by bringing writing to life, through the renewal of a real presence of the signified in the sign.

In the literature of classical modernism the instantaneousness of images is already deployed as a counter to the inherent temporality of writing, a move that is also fundamental to Thomas Lehr's novel. In this case, though, the confrontation is placed under a completely different set of signs: in Hofmannsthal's work, the "presence" of images does not appear as a threat, but rather as "the paradoxical pipe dream of language to escape itself, to transcend its mediality" (Andrée 2005: 24). According to Sabine Schneider, the literature of classical modernism had embarked on a program of "forgetting cultural codes," which was meant 
to facilitate an escape from the deficiencies of language and time, and a return to the originality and unadulterated nature of sensory experience. Thomas Lehr's novel, however, appears to take the reverse situation as its point of departure: here, the temporality of writing is not the problem, but rather the solution, whereas the dream of a life "on the threshold of the moment" in the world of timelessness has become a frightening reality. The protagonist of 42 thinks back almost nostalgically to the volatility and impalpability of the moment, which was so problematic for classical modernism:

The present was always the (distance) marker that had just disappeared under the locomotive. It was the flea in Heraclitus's hair that always jumped out of the way before the philosopher was able to squash it between his fingers, the sound that has just faded away, the hair's-breadth-wide segment of the watch face that the shadow of the second hand has just passed through, the irretrievable millimeter, the picometer, the nanometer in the mechanism of the atomic clock, ever elusive on its flight into the past, which itself no longer existed either, while the future was enduringly absent. What was, is no longer; what is, has already been; what will be, is still not there. Time ran out on us so swiftly whenever we thought about it. (Lehr 2005: 78)

It is already clear from the opening sentence that Lehr quite deliberately takes up the central paradigms of classical modernism, when he quotes a famous time metaphor from Robert Musil's The Man Without Qualities: "The train of events is a train that lays down its own tracks as it goes along." (Musil 1997: 484) Lehr, however, describes these central paradigms of the classical-modernist way of conceiving time in the preterit, thus marking the fact that, in the world of his novel, they are no longer valid. In 42, the moment lingers on indefinitely; there is thus no discrepancy between perception and designation. Frozen into a gigantic image, the world is now pure presence and, with the help of writing, has to be painstakingly re-temporalized by the isolated individual. This paradigm shift is confirmed by numerous other novels in contemporary German-language literature, in which the theme of "time" is experiencing a new boom. A noteworthy instance here is the reputedly brilliant young physicist, David Mahler, who in Daniel Kehlmann's short novel, Mahlers Zeit, manages to disprove the existence

2 "Die Gegenwart war immer die gerade unter der Lok verschwundene Markierung. Sie war der Floh in der Haarwolle des Heraklit, immer schon davongesprungen, ehe die Philosophenfinger ihn zerquetschen konnten, der eben verklungene Ton, das vom Schatten des Sekundenzeigers verlassene haarfeine Segment des Zifferblattes, der unwiederbringliche Millimeter, Pikometer, Nanometer im Zählwerk der Atomuhr, nicht zu erwischen auf der Flucht in die Vergangenheit, die es selbst doch schon nicht mehr gab, während uns die Zukunft stets noch fehlte. Was war, ist nicht mehr; was ist, ist schon gewesen; was sein wird, ist immer noch nicht da. So rasch ging uns einmal die Zeit aus, wenn wir an sie dachten.” 
of time by means of a complex formula. At the same time, like an alchemical formula, this one actually changes the physicist's own life, which increasingly slides into temporal disarray. A change in the scientific epistème thus directly affects the object of investigation, namely time itself, which cannot remain what it was before: here, too, “fleeting” time is replaced in Mahler's experience by a new temporal structure. The more fervently David pursues his theses, the less reliable time becomes, the continuity of the existing world appears to be generally endangered. Objects simply disappear before David's eyes, processes accelerate or slow down in an unreal way, memories suddenly become present. Daniel first becomes aware of this temporal change when, shortly after writing down his formula, he witnesses an accident. The truck, which runs off the road and overturns, freezes - as in Lehr's work - into a still image:

The truck stood perfectly still, balanced on two wheels, weightless. As if it could simply remain in that position. And the people were also motionless. In the middle of the road, frozen in mid-step, accompanied by the loud blaring of horns. Only a dove crossed the sky slowly, steadily beating its wings. (Kehlmann 2001: 18) ${ }^{3}$

Once again, the moment is divested of its fleeting character. The dove highlights the epiphany, but at the same time functions as a confusing factor, since it seems to belong to a different time sphere than the motionless truck. The situation thus also acquires an artificial character, with the result that it no longer appears as an immediate experience, like the emphatic momentary experiences of classical modernism, but on the contrary as alien and unreal. In Kehlmann's work, as in Lehr's, the "special" moment is a weird accident, a fateful disruption that transforms the world into a simulacrum.

In what then follows, the experience of such "presents" is replicated in almost serial fashion. Fleeting time is abolished and replaced by a new structure, in which various forms of the here and now, all placed on a largely equal footing, are played off against each other. David's every memory, his every phantasy or idea, then becomes his immediately experienced present moment. The leaps between these forms of the here and now soon take on grotesque forms. For instance, Daniel is sitting at his desk, writing a lecture, which he intends to present before a large audience:

3 "Der Lastwagen stand, ganz ruhig, auf zwei Rädern. Im Gleichgewicht und schwerelos. Als könnte es so bleiben. Und auch die Menschen waren erstarrt. Mitten auf der Straße, im Laufen, unter den schweren Akkorden der Hupen. Nur eine Taube durchkreuzte langsam, mit gleichmäßigem Flügelschlag, den Himmel.” 
He had such a clear image of it in his mind that he was amazed when it suddenly - happened. And he found himself in the silent, many-eyed lecture hall, and people looked at him, so many of them, and waited for him to speak. His notes lay before him. He fixed his eyes on them and strove to get his nervousness under control; breathe deeply, he thought, I just have to breathe deeply; and he listened to his voice, but he didn't quite manage to focus on what it was saying. His thoughts wandered, for a moment he saw the sea very clearly before him, and detected the odor of seaweed, wondered if in reality he wasn't still there, and whether the lecture hall was only a product of his imagination; and then he felt himself lying in the grass [...], and an ant crawled along his neck, tickling him (Kehlmann 2001: 81). ${ }^{4}$

And so it continues, with concatenated temporal leaps between different, equally-weighted moments of the present. The cognition of the moment is here no longer characterized by retrospection, but by productivity: linguistic conceptions are not abstractions of original experiences, they now actually construct these experiences. The media-theoretical paradigm at work here is based not on reference, but on programming: like a computer code, language now creates the perceptual images that are immediately experienced as a lived present moment. If the problem of classical modernism consisted in failing to attain the primary reality of direct perception because it was unable to overcome the secondary world of writing, in Kehlmann's work the relationship is reversed: every perception is based on programming, which for its part remains hidden behind the apparent immediacy of the images and sounds. As a kind of source code, writing has inscribed itself into reality, which is why David, instead of describing reality with his formulas, is carrying out a cybernetic manipulation of its internal organization.

Thus, in the words of Friedrich Kittler, writing no longer operates as the medium of a "hermeneutic" interpretation of the world, but as a "programmed-programming" code (Kittler 1995: 31). The novel therefore acquires a distinctly poetological dimension: while Marcel - David's best friend, who is actually a writer - juxtaposes "short descriptions of everyday things" in his texts, which can no longer be formed into a narrative and thus indicate the crisis of a refer-

\footnotetext{
4 "Er malte es sich so deutlich aus, dass er verblüfft war, als es plötzlich - geschah. Und er sich vor dem Saal fand, dem stummen, vieläugigen, und Menschen ihn ansahen, so viele davon, und darauf warteten, dass er sprach. Seine Notizen lagen vor ihm. Er heftete den Blick darauf und bemühte sich, seine Nervosität niederzukämpfen; tief atmen, dachte er, ich muss nur tief atmen; und er hörte seiner Stimme zu, aber es gelang ihm nicht ganz, ihr zu folgen. Seine Gedanken schweiften ab, für einen Moment sah er sehr klar das Meer vor sich und spürte den Geruch von Tang und fragte sich, ob er nicht eigentlich noch dort und dieser Saal nur ein Erzeugnis seiner Phantasie war; und dann fühlte er sich im Gras liegen [...], und eine Ameise krabbelte kitzelnd an seinem Hals entlang [...].”
} 
ential access to reality, for David, who is ensconced in the discourse network 2000, every act of writing is an act of construction, so that perceptions and memories, as well as narrative connections, thus are newly created in every act of writing.

According to Vilèm Flusser, writing that has become a code is now the source of a world of new, synthetic images that replace "real," "original" perceptual images. ${ }^{5}$ It is therefore not surprising that David Mahler's research is primarily aimed at transforming his own perception of the world into columns of figures and formulas, as if he were deciphering the code of a perfect, all-encompassing computer simulation (Kehlmann 2001: 55-56). Logically enough, this code does not appear to him as an image, but as the root cause of the world: "Numbers move through an infinitely distant mind; and the world becomes reality" (Kehlmann 2001: 66-67). In this new pictorial world, time can suddenly be instantaneously overcome, but - as in Thomas Lehr's work - these triumphs over time become visions of absolute hell. At one point in the novel, in a clear allusion to Robert Musil's Young Torless, Kehlmann has his protagonist lie in the grass, amazed at the boundlessness of the sky. In the same situation, Torless had once lamented the eternal alienation and falseness of this experience of pictorial totality. His idea of coming nearer to heaven, and, like the Biblical Jacob, of being able to "climb up and into it...if only one had a long, long ladder," ends in the well-known failure of the human mind when confronted with the visuality of the moment. The ladder is never long enough to reach heaven: "the further he penetrated, raising himself on his gaze, the further the blue, shining depth receded" (Musil 1986: 71-72). Here, understanding is opposed to true experience: "somewhere between experience and comprehension [...] incomparability" reigns: "Yet it is always of such a nature that what in one moment we experience indivisibly, and without question, becomes unintelligible and confused as soon as we try to link it with chains of thought to the permanent store of what we know.” (Musil 1986: 73) ${ }^{6}$

5 "The images that program us are [...] not of the kind that prevailed before the invention of book printing. Television programs are unlike Gothic stained glass windows, and the surface of a soup can is unlike the surface of a Renaissance painting. The difference, in short, is this: [...] Pre-modern man lived in a world of images which signified the 'world'. We live in a world of images that try to define theories about the 'world'. This is a revolutionary new situation." (Flusser 2005: 22-23)

6 "Immer aber ist es so, dass das, was wir in einem Augenblick ungeteilt und ohne Fragen erleben, unverständlich und verwirrt wird, wenn wir es mit den Ketten der Gedanken zu unserem bleibenden Besitz fesseln wollen." 
The "chain of thoughts" is a temporal link into the infinite, an infinite regress of the chain of signs, which can never catch up with the reality to which it refers. Truth is obscured by conceptual thought: "casual words" flow over the moment, blotting it out (Musil 1986: 21). While for Torless the sky seems to be so far away that the ladder of reflection he tries to build to it can never reach it, when David finds himself in the same situation, the sky is "suddenly very close," it shuts all other perceptions out, and hypnotizes the disturbed physicist by virtue of a "color he had never seen before." The sky still fills his entire visual field, when, drawing on his last strength, David closes his eyes:

He didn't move. He tried to inhale, but there was no air. The sky embraced him firmly. Even the grass stood quite still, could no longer be felt. The sky came closer. He still could not breathe.

He closed his eyes with all his might. It didn’t help: the sky remained visible. A fit of panic, of helpless, burning fear ran through his body. It went on and on. And still it went on. (Kehlmann 2001: 89-90) ${ }^{7}$

Here the overcoming of time seems to have succeeded in a horrifying fashion: the moment really does come to a halt, the sea of boundlessness "embraces" David "firmly." In contrast to Torless, who is unable to overcome the limitations of the mind in any lasting way, David is no longer able to find his way back to reality from the "momentary" abolition of time; it takes a sudden loss of consciousness to free him from the prison of total visibility. For Torless, "pictorial" infinity is reduced to a linguistic "concept"; for Mahler, it becomes a total experience of the image which excludes all differential operations. The crisis of time in Kehlmann's novel is thus no longer characterized by the "mediacy" of conceptual understanding, but by the "immediacy" of perceptions, which resist all cognitive processing. These are no longer "original" or "authentic," but artificial: it is no coincidence that they remind one of a computer system crash, which can only be fixed by a reboot; after all, they are based on the programming of an "infinitely distant mind." As an avant-garde practitioner in the field of physics, Mahler himself triggers this temporal disruption. As in the novels from around 1900 , the linear model of time is initially subjected to a critique and provisionally replaced by a new time structure, by "Mahler's time." In this case, however, unlike the texts from the turn of the century, the rebellion clearly goes well be-

7 "Er bewegte sich nicht. Er versuchte einzuatmen, aber da war keine Luft. Der Himmel umschloss ihn fest. Selbst das Gras stand ganz ruhig, war nicht mehr zu fühlen. Der Himmel rückte näher. Er konnte noch immer nicht atmen. / Mit aller Kraft schloss er die Augen. Es half nicht: Der Himmel blieb sichtbar. Ein Anfall von Panik, von hilfloser, brennender Angst lief durch seinen Körper. Es dauerte an, immer noch. Und immer noch. Und immer noch.” 
yond the intended goal: the linear order is no longer automatically restored, but is replaced by a different order of time, from which there is no way back to the old interval structure, and which ultimately destroys the subject "Mahler," whom the new order was supposed to serve.

As already pointed out, the temporal derailments in both Lehr and Kehlmann are connected with experiences that are related to the temporal modes of the audiovisual media. Audiovisual technical media manifestly produce an absolute "tyranny of proximity," which leads to a "leveling of symbolic difference and symbolic distance" (Großklaus 2004: 180). In the novels in question, the allusions to the ways in which these "new" media function are unmistakable: as if God were playing with the remote control of a cosmic DVD player, time jumps back and forth, with episodes alternating in time-lapse or slow motion. In the novel Cliehms Begabung (Cliehm's Talent) by Michael Wallner, for example, in which, as in Lehr's work, a physicist disproves the existence of time and thereby ends up in the midst of temporal calamities, the temporal paradoxes are coupled directly with mechanisms of media. Cliehm, the novel's protagnonist, uses his memory like a video recorder on which he can rewind and fast-forward his life: "Cliehm is on the lookout for memory. Go backwards! he calls. Now!” (Wallner 2000: 60). Like Kehlmann's protagonist, Cliehm jumps back and forth between the different phases of his life, each one immediately becoming the new here-and-now as soon as Cliehm activates it. In Wallner's work, time is indeed ultimately reduced to the present: every past moment not only continually becomes the present moment again, it can also unfold differently each time it is recalled, which is only logical. "I've been here before," Cliehm complains to his memory, after one of his leaps in time: "What am I supposed to do here a second time?" But his memory responds: "It's not the second time. It's now" (Wallner 2000: 151). Every conceivable moment in time becomes the here-andnow: "It's not the past that I'm shaping! It's not the future that I'm changing. It's the present," Cliehm realizes (Wallner 2000: 155).

As a result, however, sooner or later Wallner's time researcher loses track of the chronology of his life. Since each newly made decision in the past necessarily affects the future, an ever-increasing multiplicity of biographical permutations soon arises, which are mutually exclusive but nevertheless exist parallel to each other. For Cliehm, time is thus transformed into a network of different parallel courses of action, amongst which he always only experiences certain alternating moments in the present. In each case, a considerable effort is required to establish the connections: "What happened before? How did I get into this situation?," he asks himself over and over again: "Traveling in time, thinks Cliehm, 
panic-stricken. Forwards or backwards? Tilly is standing opposite me, he notes, behind her is a café. When am I, damn it?!" (Wallner 2000: 181). ${ }^{8}$

This kind of leaping back and forth between different parallel time sequences can also be found in Helmut Krausser's UC or Juli Zeh's Schilf. The model of time that underlies this kind of fiction is described as the "multiverse," a concept that is widespread in various spheres of popular culture, especially in mystery films, and which probably goes back to Borges's famous story, The Garden of Forking Paths (Baulch 2003). Here Borges introduces the concept of a literature that does not distinguish between reality and possibility, but rather, in a gigantic network of parallel and irreconcilable stories, retroactively cancels every decision that has ever been made. Theoretically, this idea is illustrated by a novel in the novel, the gigantic encyclopedia of a forgotten Chinese author:

In all fictional works, each time a man is confronted with several alternatives, he chooses one and eliminates the others; in the fiction of Ts'ui Pên, he chooses - simultaneously - all of them. He creates, in this way, diverse futures, diverse times which themselves also proliferate and fork. (Borges 1964: 26) ${ }^{9}$

Instead of a linear plot logic, the work thus consists of a network of different futures, pre-histories, and parallel worlds, all of which are placed on an equal footing and which, as a result of their incompatibility, reveal the constructed nature of each one of them. This world is described as "a growing, dizzying net of divergent, convergent and parallel times," in which nothing is ever finally decided: "This network of times which approached one another, forked, broke off, or were unaware of one another for centuries, embraces all possibilities of time." For the protagonist of the narrative - who finds himself in the middle of the war, is being pursued and is pursuing others, and who for several reasons is under significant time pressure - this idea offers a sense of relief, an aesthetic escape from linear time: he knows that in another world he will not kill and not die; in this other world, the other paths that he could have taken in life have become real.

This concept of multiversal time is especially prominent in Helmut Krausser's novel, UC. Here, the protagonist, the distinguished conductor Arndt Her-

8 "Unterwegs in der Zeit, denkt Cliehm panisch. Vorwärts oder rückwärts? Tilly steht mir gegenüber, stellt er fest, hinter ihr ist ein Café. Wann bin ich, verdammt?!”

9 "En todas las ficciones, cada vez que un hombre se enfrenta con diversas alternativas, opta por una y elimina las otras; en la del casi inextricable Ts'ui Pen, opta - simultáneamente por todas. Crea, así, diversos porvenires, diversos tiempos, que también proliferan y se bifurcan.” 
mannstein, appears to be lost in this multiverse: for instance, an unusually harmonious night with his wife Laura - who now suddenly claims to have never been married to him - seems, on the occasion of their next (as usual, catastrophic) encounter to have never taken place; and a London prostitute appears to be identical with a very pretty girl from Arndt's former school, but who in fact became a doctor in Germany. With every change of place, Arndt seems to jump into another life, in which the people with whom he is mixing have also taken other pathways in life. Arndt himself sees the situation as follows:

It could be that something that has never happened constitutes a virtual variant of my existence. Maybe that's the solution: everything that I might have been capable of at some point has subsequently become real, on an equal footing with what actually happened. (Krausser 2003: 46) $^{10}$

It would seem, then, that Krausser's protagonist has irrevocably lost his way in the network of forking paths, a network that still offered Borges's protagonist an opportunity intellectually to transcend the monotony of his existence. In Krausser's work, however, the network of narratives has left the inner space of the novel within the novel and has mutated into the inner-fictional structural principle of reality itself. In Krausser, the entry into the multiverse is also initially interpreted as a liberating disruption of the uniformity and irreversibility of linear time, as offering access to "another time," which at first makes it seem as if Krausser is simply a dedicated follower of Borges's literary model. The abolition of time in a series of diverse and "incompossible" presents seems to make it possible to understand life as a freely malleable work of art, to free literature from all mimetic demands made on it, and to "seek one's salvation in a counter reality" (Krausser 2003: 202), as it is explicitly formulated at one point. Cliehm, too, is delighted with his remarkable "gift," and ultimately he even ends up developing powerful fantasies of omnipotence: "Nothing is moving, except on the paths in my head. I can be faster than light or infinitely slow. I am way out there, where the sun is no longer to be seen. I am right inside the ice. I travel. It's my gift." (Wallner 2000: 301) ${ }^{11}$

10 "Es könnte sein, dass sich manches, was nie geschehen ist, als virtuelle Variante meiner Existenz konstituiert. Das ist vielleicht die Lösung: Alles, dessen ich irgendwann einmal fähig gewesen wäre, ist nachträglich faktisch geworden, gleichberechtigt mit dem tatsächlichen Geschehen."

11 "Nichts bewegt sich, außer auf den Wegen in meinem Kopf. Ich kann schneller sein als das Licht oder unendlich langsam. Ich bin weit draußen, wo die Sonne nicht mehr zu sehen ist. Ich bin im Innern des Eises. Ich reise. Es ist meine Begabung." 
However, as we learn at the end of the novel, Cliehm is actually lying in a coma. Adrian, the protagonist of Thomas Lehrs 42, has long been dead, and he is now experiencing the second of his death as eternity with those who died at the same moment as he did. And even for Krausser's and Kehlmann's protagonists, the freedom they supposedly attain by being temporally uprooted comes first at the price of their social death and ultimately their physical death. All these novels describe, in the first place, processes of isolation, paths leading to a solipsism in which the protagonists end up face to face solely with their own imaginations; the products of a mind that is no longer connected to the external world, but rather, following the logic of a computer, programs and simulates its own worlds and perceptions. In this situation, it is precisely the aesthetic approaches of classical modernism from Musil to Borges, namely the regression into the "pre-semiotic immediacy" (Steiner 1996: 173) of purely present experience, and the pluralization of time into conflicting but equally valid "fictions," that become the hallmarks of the crisis: the authorial power of determination over the "multiverse" of equally valid pasts is lost and present experience turns into an oppressive lack of distance. The epiphanies of classical modernism, in which the interval that is constitutive of time is supposed to be overridden or bypassed, are associated with anxiety-laden ideas about the temporal forms of the new image media, and in this way are revealed to be inadequate, or shortsighted. Placed in opposition to this is the protagonists' fundamental need for unequivocal historical or biographical contexts, a longing for the old, linear, fleeting time. As Ursula Heise puts it: "The time of the individual mind no longer functions as an alternative to social time" (Heise 1997: 7).

Fully in keeping with Jacques Derrida's critique of logocentrism (Derrida 1976), the novels of Kehlmann, Krausser, and Lehr thus deconstruct the mental constructs of immediacy, which are bound to the assertion that writing is subordinate. In these works, it is no accident that the presentist experience of the world is marked by its artificiality; it points to the mediating mechanisms of signs, codes, and technical media that are invisibly at work in it. Experiences of the present thus become recognizable as components of a simulation and therefore as secondary, while access to the source code of this reality threatens to prove elusive. The novels can thus be read as disruptions of a metaphysics of presence, which has apparently developed a new, calamitous efficacy in a reality structured by immersive and digital media. As portrayed in contemporary literature, temporal disruptions are no longer directed against a normalized understanding of time, against incremental time, against economization, unification and measurement, as was the case in the literature of classical modernism. Rather - as second order disruptions - they are directed against a potent aesthetic figure of temporal disruption, whose significance for contemporary media cul- 
ture they uncover, and whose inherent promises of meaning they expose as illusory.

\section{Works Cited}

Andrée, Martin (2005) Archäologie der Medienwirkung. Faszinationstypen von der Antike bis heute (München: Fink).

Barthes, Roland (1981) Camera Lucida. Reflections on Photography (New York: Farrar, Straus and Giroux).

Baulch, David M. "Time, Narrative, and the Multiverse: Post-Newtonian Narrative in Borges's 'The Garden of the Forking Paths' and 'Blake's Vala or the Four Zoas'," The Comparatist 27, 56-78.

Borges, Jorge Luis (1964) “The Garden of the Forking Paths," in Labyrinths: Selected Stories \& Other Writings (New York: New Directions).

Braun, Christina von (1999) "Ich habe Zeit. Das taktlose Geschlecht," in Zeitsprünge, ed. Ursula Keller (Berlin: Vorwerk), 101-130.

Derrida, Jacques (2007) "A Certain Impossible Possibility of Saying the Event," Critical Inquiry 33, $441-461$.

Derrida, Jacques (1976) Of Grammatology (Baltimore: John Hopkins University Press).

Flusser, Vilém (2005) Medienkultur (Frankfurt a.M.: Fischer).

Galison, Peter (2003) Einstein's Clocks and Poincaré's Maps. Empires of Time (New York: W.W. Norton \& Company).

Großklaus, Götz (2004) Medien-Bilder. Inszenierung der Sichtbarkeit (Frankfurt a.M.: Suhrkamp).

Heise, Ursula K. (1997) Chronoschisms. Time, Narrative and Postmodernism (Cambridge: Cambridge University Press).

Hofmannsthal, Hugo von (1991) "Die Briefe des Zurückgekehrten," in Sämtliche Werke XXXI: Erfundene Gespräche und Briefe, ed. Ellen Ritter (Frankfurt a.M.: Suhrkamp), 151-174.

Kehlmann, Daniel (2001) Mahlers Zeit (Frankfurt a.M.: Suhrkamp).

Kittler, Friedrich (1995) Aufschreibesysteme 1800-1900 (München: Fink).

Lehr, Thomas (2005) 42 (Berlin: Aufbau).

Middeke, Martin (2002) "Zeit und Roman: Zur Einführung," in Zeit und Roman.

Zeiterfahrungen im historischen Wandel und ästhetischer Paradigmenwechsel vom sechzehnten Jahrhundert bis zur Postmoderne, ed. Martin Middecke (Würzburg: Königshausen \& Neumann), 1-20.

Mumford, Lewis (1934) Technics and Civilization (New York: Harcourt, Brace and Co.). Musil, Robert (1997) The Man Without Qualities (London: Picador).

Musil, Robert (1986) Selected Writings: Young Torless, Three Women, The Perfecting of a Love, and Other Writings, ed. Burton Pike (New York: The Continuum Publishing Company).

Nietzsche, Friedrich (1997) “On the Uses and Disadvantages of History for Life," in Untimely Meditations, ed. Daniel Breazeale (Cambridge, UK: Cambridge University Press).

Schneider, Sabine (2006) Verheißung der Bilder. Das andere Medium in der Literatur um 1900 (Tübingen: Max Niemeyer).

Stegemann, Bernd (2015) Lob des Realismus (Berlin: Theater der Zeit). 
Steiner, Uwe C. (1996) Die Zeit der Schrift. Die Krise der Schrift und die Vergänglichkeit der Gleichnisse bei Hofmannsthal und Rilke (München: Fink).

Wallner, Michael (2000) Cliehms Begabung (Frankfurt a.M.: Frankfurter Verlagsanstalt). 